Reprod. Nutr. Dévelop., 1987, 27 (1 A), 21-28.

\title{
Plasma renin activity and aldosterone concentration in sodium-depleted cattle following ACTH or metoclopramide injection
}

\author{
F. RIAD, J. GIRY, J.-P. BARLET
}

U.A. C.N.R.S. 041123, I.N.R.A. Theix, F-63122 Ceyrat.

Summary. Adrenocorticotropic hormone (ACTH) treatment $\left(7 \mu \mathrm{g} \cdot \mathrm{kg}^{-1}\right.$ body weight) induced an increase in plasma aldosterone concentration in both Na-deficient heifers (following saliva loss after right parotid duct cannulation) and Na-replete heifers, but had no significant effect on plasma renin activity in either of these groups. The dopamine antagonist, metoclopramide, injected i.v. $\left(1 \mathrm{mg} \cdot \mathrm{kg}^{-1}\right.$ body weight) did not modify plasma renin activity, aldosterone or cortisol concentrations in either group. These results indicate that dopamine did not play a major role in the regulation of aldosterone secretion in $\mathrm{Na}$ replete or Na-depleted heifers.

\section{Introduction.}

Sodium ( $\mathrm{Na}$ ) deficiency can be easily induced by salivary loss following parotid duct cannulation in sheep (Blair-West et al., 1970) or cattle (Bell, Drury and Sly, 1981 ; Riad et al., 1986). In cattle, plasma aldosterone (aldo) concentration increases sharply during $\mathrm{Na}$ deficiency (Riad et al., 1986). However, in such calves or bulls, angiotensin II infusion has no significant effect on plasma aldo concentrations, which do not return to basal levels during treatment with captopril, an angiotensin-converting enzyme inhibitor (Riad, Giry and Barlet 1987). Thus, one might postulate that other factors, such as adrenocorticotropic hormone (ACTH) and/or dopamine (Sowers et al., 1983), might regulate aldo secretion in Na-deficient ruminants. The aim of the present study was to determine the possible influence of ACTH or dopaminergic inhibition - via metoclopramide (MCP) administration (Day and Blower, 1975 ; Peringer et al., 1976) - on plasma renin activity (PRA) and plasma aldo concentration in $\mathrm{Na}$ deficient heifers.

\section{Material and methods.}

Animals and treatments. - Twelve 10-month-old Charolais heifers weighing $280 \pm 10 \mathrm{~kg}$ (mean \pm SEM) were used. They received a diet of $2.5 \mathrm{~kg}$ of grain concentrate and lucerne chaff and $8 \mathrm{~kg}$ of rye grass hay, making a convenient 
daily intake of $35 \mathrm{~g}$ of potassium (K) and $10 \mathrm{~g}$ of $\mathrm{Na}$ (Guéguen, 1978). Each animal had free access to tap water.

Na-depletion. - Under halothane anaesthesia the right parotid duct of each heifer was cannulated using reentrant polyethylene tubing (Riad et al., 1986). Each animal was allowed at least 7 days to recover from surgery. $\mathrm{Na}$ depletion was induced in the heifers by saliva loss from the right parotid gland for $24 \mathrm{~h}$. Blood and saliva samples (10 and $8 \mathrm{ml}$, respectively) were collected every 4 hours for $24 \mathrm{~h}$.

ACTH infusion. - At 9 a.m., four 24-h Na-depleted heifers and four Na-replete heifers received an initial bolus injection of ACTH $1-24\left(3.5 \mu \mathrm{g} \cdot \mathrm{kg}^{-1}\right.$ body weight ; Synacthene, Ciba-Geigy, Rueil-Malmaison, France) via the left jugular vein, followed by the same dose infused over a 1-hour period. The ACTH was dissolved in $0.9 \% \mathrm{NaCl}(40 \mathrm{ml})$ in each case. Four control Na-replete heifers received the same volume of vehicle alone in the same way. Blood samples $(10 \mathrm{ml})$ were obtained at - 10 and 0 min before $A C T H$ injection, then at 30 and 60 min during ACTH infusion and 120, 180 and 240 min afterwards.

Metoclopramide administration. - One month later, $4 \mathrm{Na}$-depleted and $4 \mathrm{Na}$ replete heifers received an i.v. injection of $M C P\left(1 \mathrm{mg} / \mathrm{kg}^{-1}\right.$ body weight ; Primperan, Laboratoire Delagrange, Paris) et $9 \mathrm{a} . \mathrm{m}$. Blood samples $(10 \mathrm{ml})$ were collected at -10 and 0 min before MCP injection and then at 10, 20, 30, 60, 90 and 120 min after drug administration. Blood was centrifuged at $4{ }^{\circ} \mathrm{C}$ and the plasma was collected and frozen until analysis.

Methods. - PRA was determined by radioimmunoassay (RIA) of angiotensin I using a Gammacoat ${ }^{125}$ | plasma renin activity radioimmunoassay kit (Clinical Assays, Travenol Laboratories, Cambridge, USA) (Safwate, 1985). Method sensitivity was 0.01 pmoles and intra and interassay variabilities were 8 and $10 \%$, respectively.

Plasma aldo concentrations were determined by RIA (Giry and Delost, 1977). Method sensitivity was 27 pmoles. Intra and interassay variabilities were 9 and $10 \%$, respectively.

Plasma cortisol concentration was measured by competitive protein binding assay (Dalle and Delost, 1976). Assay sensitivity was 0.280 nmoles. Intra and interassay variabilities were 7 and $10 \%$, respectively.

Plasma (or saliva) $\mathrm{Na}$ and $\mathrm{K}$ concentrations were determined by flame photometry (Perkin Elmer 400).

The results were expressed as the mean \pm SEM. The statistical significance of the differences observed between treated and control groups was calculated using the Mann-Whitney U-test. One-way analysis of variance was used to observe the influence of ACTH or MCP in Na-deficient heifers.

Results.

Consequences of Na-depletion. - Na depletion by $24 \mathrm{~h}$ salivary loss following right parotid duct cannulation induced a $28 \pm 4$-liter salivary loss containing 
$3782 \pm 275$ mmoles of $\mathrm{Na}$ and $300 \pm 100$ mmoles of $\mathrm{K}$ (fig. 1). Such a depletion induced a progressive rise in PRA and plasma aldo concentration (fig. 2). PRA and plasma aldo concentration increased from $0.9 \pm 0.1$ pmoles Al. $\mathrm{ml}^{-1} \cdot \mathrm{h}^{-1}$ and $31 \pm 5$ pmoles $^{-1}$, respectively, before depletion, to $6.1 \pm 1.9$ pmoles Al. $\mathrm{ml}^{-1} \cdot \mathrm{h}^{-1}$ $(P<0.01)$ and $831 \pm 47$ pmoles.liter ${ }^{-1}(P<0.01)$, respectively, at the end of

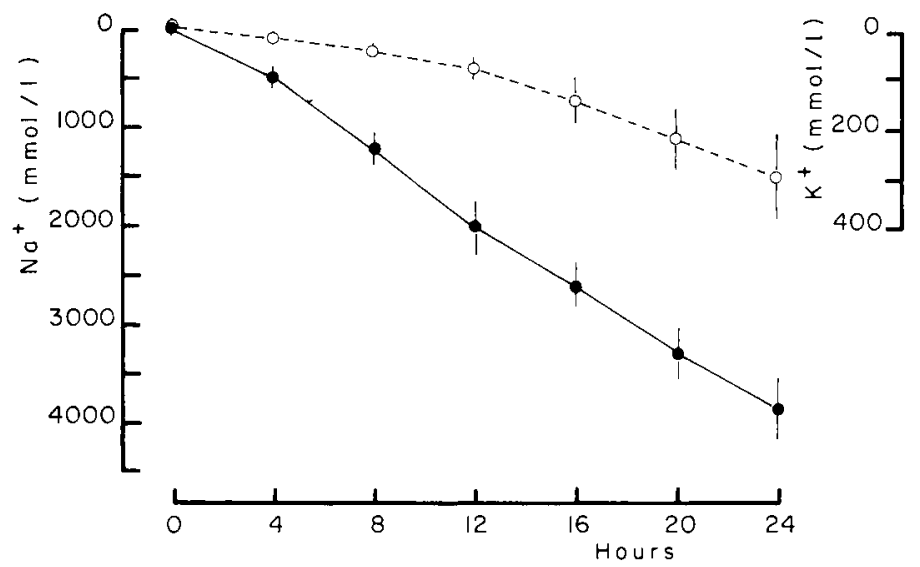

FIG. 1. - Cumulative electrolyte loss during 24-hour Na-depletion induced by salivary drainage in 4 heifers. (Mean \pm SEM). ( $\mathrm{Na}$ : solid line ; $\mathrm{K}$ : dashed line).
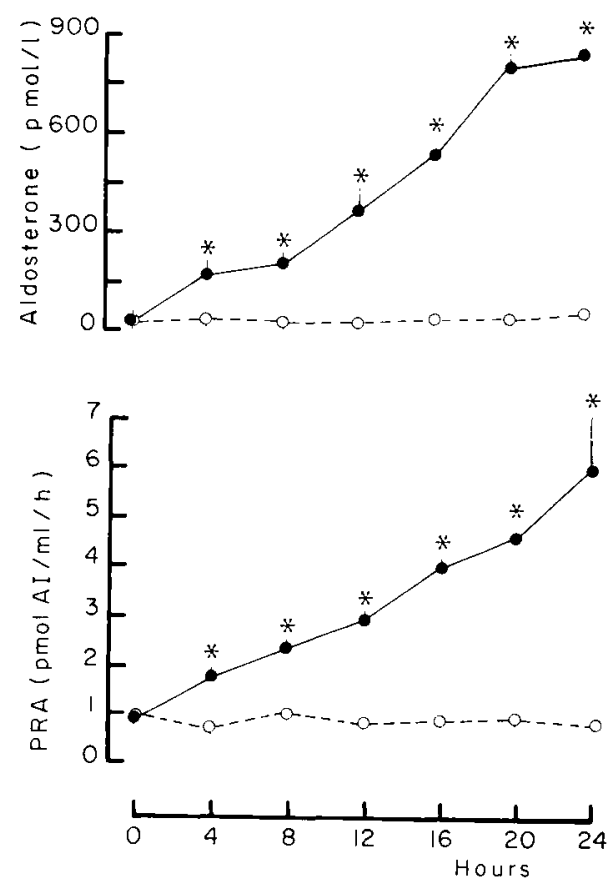

FIG. 2. - Changes in plasma aldosterone concentration and plasma renin activity (PRA) during 24-hour Na-depletion in 4 heifers (solid line) and in 4 control animals (dashed line). (Mean \pm SEM ; ${ }^{*} P<0.01$ ). 
$\mathrm{Na}$ depletion. In the controls no significant variation was observed in PRA and plasma aldo concentration. During $\mathrm{Na}$ deficiency, salivary $\mathrm{Na}$ concentration decreased from $145 \pm 5$ mmoles.liter ${ }^{-1}$ to $122 \pm 9$ mmoles.liter $^{-1}(P<0.01)$, while salivary $K$ concentration increased from $4.6 \pm 0.1$ mmoles.liter $^{-1}$ to $16.6 \pm 3.0$ mmoles. liter $^{-1}(P<0.01)$ and the salivary $\mathrm{Na} / \mathrm{K}$ ratio decreased from $33.3 \pm 0.9$ to $8.9 \pm 2.8(P<0.01)$. Na deficiency had no significant effect on plasma $\mathrm{Na}$ or $\mathrm{K}$ concentration.

Influence of intravenous ACTH infusion. - in Na-replete heifers, ACTH (7 $\mu \mathrm{g} \cdot \mathrm{kg}^{-1}$ body weight) significantly increased plasma aldo concentration (pmoles.liter ${ }^{-1}$ ) from $32 \pm 5$ to $81 \pm 16$ thirty min after the beginning of the infusion

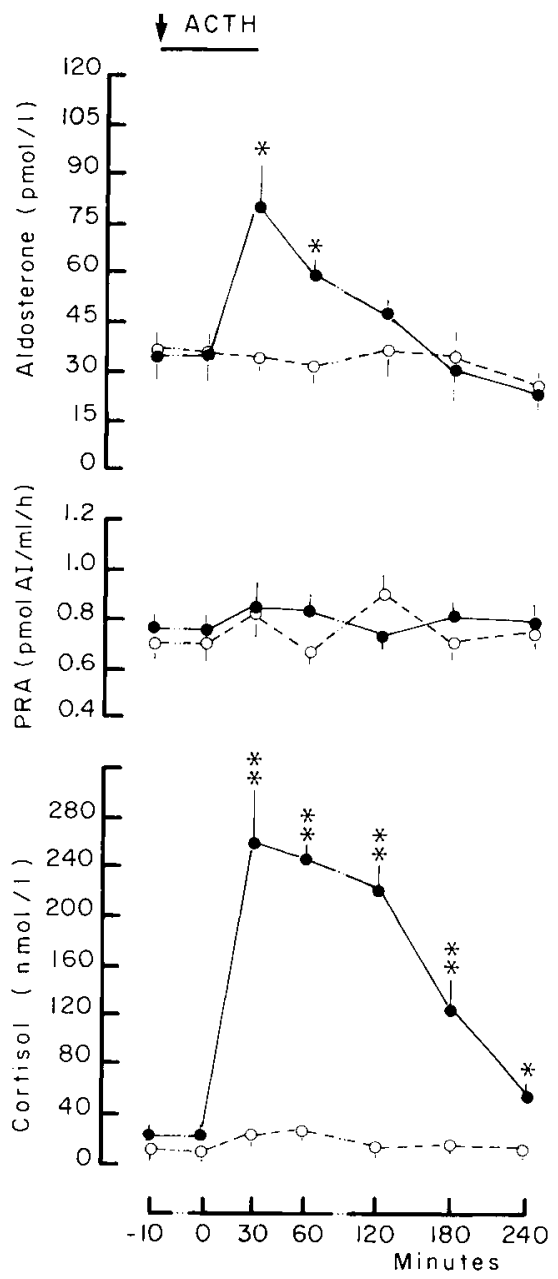

FIG. 3. - Plasma cortisol and aldosterone concentrations and plasma renin activity (PRA) in $4 \mathrm{Na}$ replete heifers (solid line) following i.v, administration of ACTH (7 ng. $\mathrm{kg}^{-1}$ body wt) (dashed line : 4 control animals). (Mean \pm SEM; ${ }^{*} P<0.05 ;{ }^{*} P<0.01$, comparison between treated and control animals). 
and when it was infused again for $1 \mathrm{~h}$. Plasma cortisol concentration (nmoles.liter ${ }^{-1}$ ) increased from $21 \pm 3$ to $226 \pm 39$ in the same way. ACTH had no significant effect on plasma PRA (pmoles Al. $\mathrm{ml}^{-1} \cdot \mathrm{h}^{-1}$; mean value $0.80 \pm 0.07$ in treated animals vs $0.77 \pm 0.08$ in controls) (fig. 3 ).

In Na-depleted heifers ACTH treatment increased plasma aldo concentration (pmoles.liter ${ }^{-1}$ ) from $792 \pm 30$ to $1010 \pm 42$ at the end of the infusion. Plasma cortisol concentration (nmoles.liter ${ }^{-1}$ ) increased in the same way from $26 \pm 8$ to $261 \pm 12$. PRA did not vary significantly (mean value : $4.5 \pm 0.8$ pmoles Al. $\mathrm{ml}^{-1} \cdot \mathrm{h}^{-1}$ ) (fig. 4).
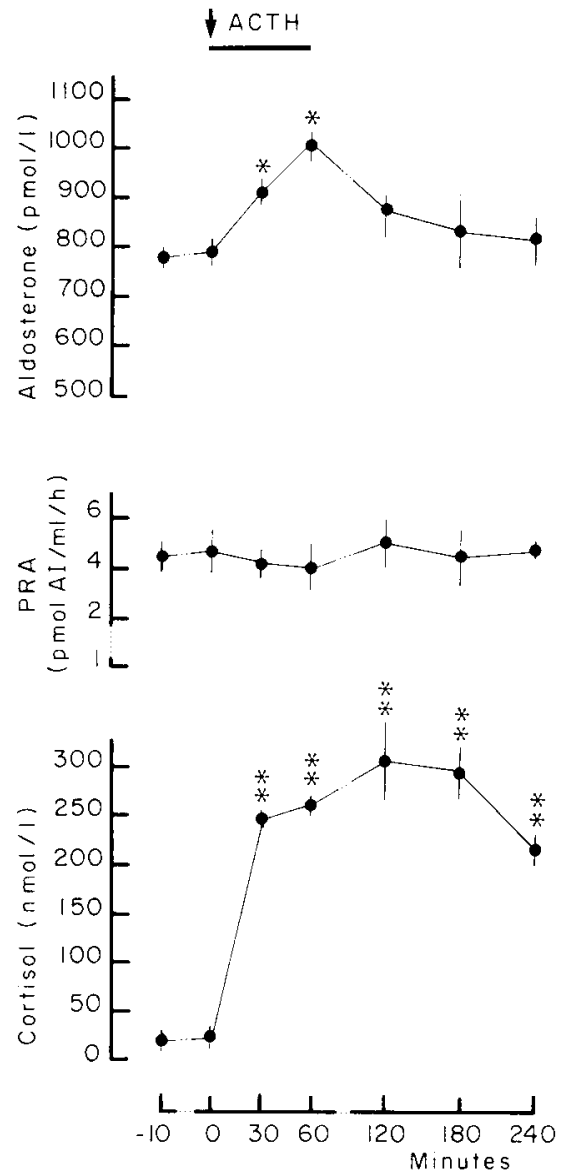

FIG. 4. - Plasma cortisol and aldosterone concentrations and plasma renin activiy (PRA) in $4 \mathrm{Na}$-depleted heifers following i. v. administration of ACTH (7 $\mathrm{ng} . \mathrm{kg}^{-1}$ body wt) (Mean \pm SEM : ${ }^{*} \mathrm{P}<0.05 ;{ }^{*} \mathrm{P}<0.01$, comparison with values at time 0 ).

Influence of meıoclopramide administration. - In Na-replete and Nadepleted heifers, MCP had no significant effect on either PRA or plasma aldo or cortisol concentration (fig. 5). 

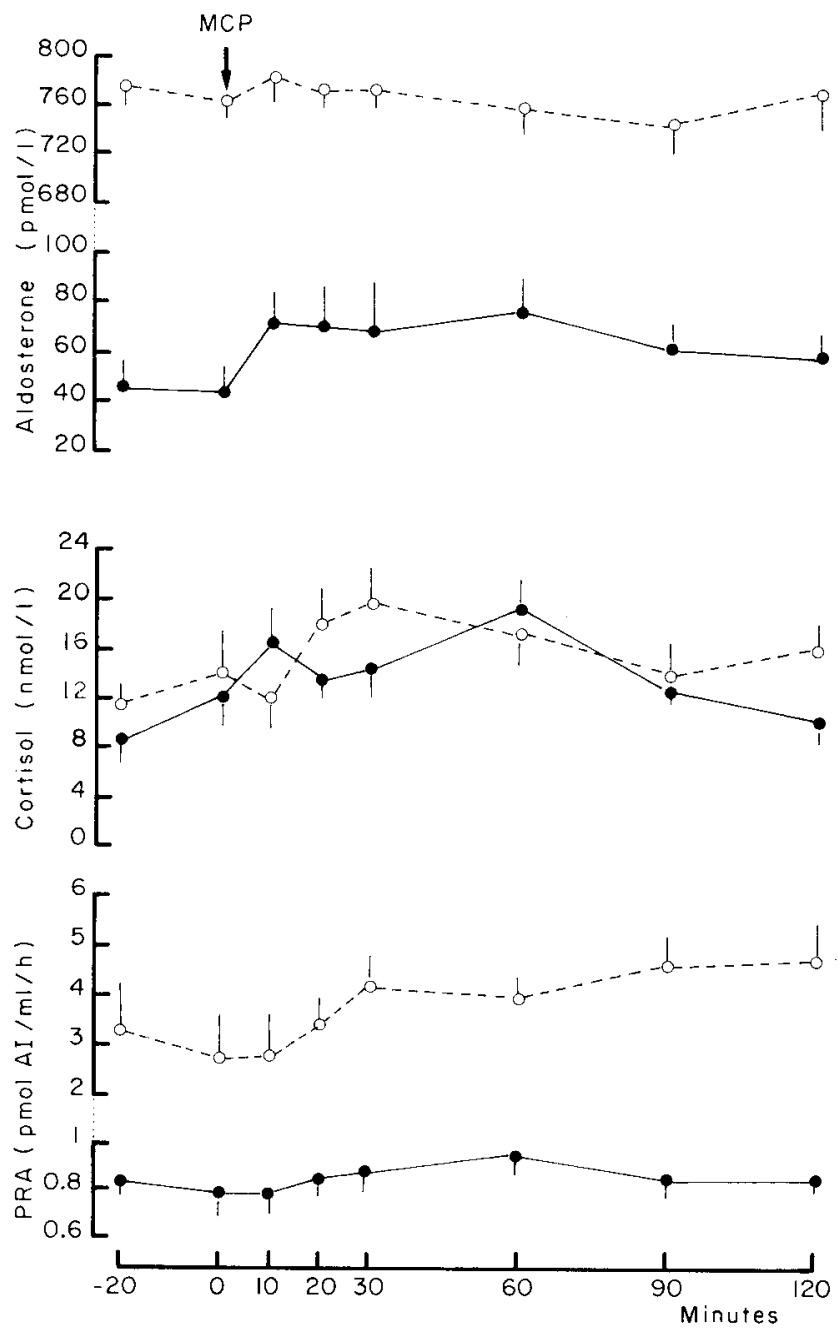

FIG. 5. - Plasma renin activity (PRA), plasma cortisol and aldosterone concentrations in $4 \mathrm{Na-}$ replete heifers (solid line) and in 4 Na-depleted heifers (dashed line) following metoclopramide (MCP) i.v. injection (1 $\mathrm{mg} . \mathrm{kg}^{-1}$ body wt). (Mean \pm SEM).

\section{Discussion.}

Experimental $\mathrm{Na}$ depletion in 10-month-old heifers, induced by loss of saliva from the right parotid gland over $24 \mathrm{~h}$, progressively increased PRA and plasma aldo concentrations (fig. 2). Similar results have been reported in sheep (BlairWest et al., 1970) and following dietary $\mathrm{Na}$ restriction in man (McCaa et al., 1981). In Na-replete and Na-depleted heifers, ACTH induced a significant rise in plasma aldo and cortisol concentrations. However, in each group the rise in plasma cortisol was significantly more pronounced and more intense than that 
observed for aldo (figs 3,4). Similar results have been reported in humans (McCaa et al., 1981) and rats (Kinson and Singer, 1968). ACTH had no effect on either PRA (figs. 3,4 ) or plasma $\mathrm{K}$ concentration in any group, indicating a direct effect of that hormone on zona glomerulosa cells. Similar results have been reported in human volunteers on an unrestricted $\mathrm{Na}$ intake and infused with a low dose (1.25 ng) of ACTH (Nicholls, Espiner and Donald, 1975). The rise in plasma aldo concentration measured after ACTH treatment in $\mathrm{Na}$-replete heifers $(+253 \%)$ was twice that observed after the same treatment in Na-depleted heifers $(+128 \%)$. However, the incremental increase in aldosterone following

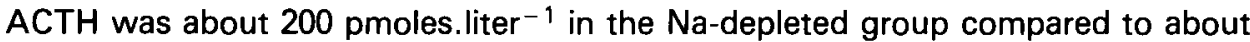
45 pmoles.liter $^{-1}$ in the replete group, suggesting that $\mathrm{Na}$ depletion potentiated aldosterone response to ACTH. This agrees well with Kojima, Kojima and Rasmussen (1985) who demonstrated that angiotensin II and ACTH interact with different receptors and stimulate aldo synthesis through different post-receptor mechanisms in bovine glomerulosa cells.

MCP had no significant effect on PRA or on plasma aldo or cortisol concentration in either Na-replete or Na-depleted heifers (fig. 5). However, MCP has been reported to increase plasma aldo and corticosterone concentrations in $\mathrm{Na}$ replete sheep (Sowers et al., 1983), indicating a dopamine inhibition on aldosterone biosynthesis. Dopamine receptors have been identified in bovine glomerulosa cells (Racz et al., 1984). In these cells, dopamine inhibits the conversion of deoxycorticosterone to aldosterone (McKenna et al., 1979). Other studies in Na-replete calves (Safwate et al., 1985) and in sheep on various $\mathrm{Na}$ balances (McDougall et al., 1981) do not support the suggestion that direct dopaminergic elements play a tonic inhibitory role in aldo secretion. The role of dopamine in modulating aldo secretion appears to be species-dependent (Sowers et al., 1981) rather than to depend on the $\mathrm{Na}$ balance of the animal (fig. 5).

In conclusion, our results demonstrate that ACTH stimulates aldosterone in both Na-depleted and Na-replete heifers. Dopamine does not appear to play a major role in the regulation of aldosterone secretion, whatever the $\mathrm{Na}$ balance of the animals.

Reçu en juillet 1986.

Accepté en octobre 1986.

Acknowledgements. - The animals used in this study were kindly supplied by Dr. M. Petit (Station des Productions Bovines et Chevalines). The metoclopramide (Primperan) was a gift of the "Laboratoires Delagrange ", Paris.

Résumé. Effets de l'ACTH et du métoclopramide sur l'activité rénine plasmatique et l'aldostéronémie chez les bovins au cours de la déplétion sodée.

L'administration intraveineuse d'ACTH (7 $\mu \mathrm{g} . \mathrm{kg}^{-1}$ de poids vif) entraîne une augmentation de la concentration plasmatique de l'aldostérone chez les génisses au cours de la déplétion sodée (induite par fuite salivaire parotidienne droite) comme chez les génisses en réplétion sodée.

Le métoclopramide (antagoniste de la dopamine) administré par voie intraveineuse (1 $\mathrm{mg} \cdot \mathrm{kg}^{-1}$ de poids vif) ne modifie pas l'activité rénine plasmatique, ni la cortisolémie ou l'aldostéronémie, quel que soit le groupe d'animaux considéré. Ces résultats montrent que la dopamine ne joue pas un rôle important dans le contrôle de la sécrétion d'aldostérone chez les génisses en réplétion ou en déplétion sodée. 


\section{References}

BELL F. R., DRURY P. L., SLY J., 1981. The effect on salt appetite and the renin-aldosterone system of replacing the depletion ions to sodium-deficient cattle. J. Physiol. (London), 295, $431-443$.

BEVILACQUA M., VAGO T., SCORZA D., NORBIATO G., 1982. Characterization of dopamine receptors by ${ }^{3} \mathrm{H}$-ADTN binding in calf adrenal zona glomerulosa. Biochem. biophys. Res. Commun., 108, 1661-1669.

BLAIR-WEST J. R., COGHLAN J. P., DENTON D. A., WRIGHT R. D., 1970 . Factors in sodium and potassium metabolism, 350-361. In PHILLIPSON A. T., Physiology of digestion and metabolism in the ruminant, Oriel Press, New York.

DALLE M., DELOST P., 1976. Plasma and adrenal cortisol concentrations in fetal, newborn and mother guinea-pigs during the perinatal period. J. Endocr., 70, 207-214.

DAY M. D., BLOWER P. R., 1975. Cardiovascular dopamine receptor stimulation antagonized by metoclopramide. J. Pharm. Pharmacol., 27, 276-278.

GIRY J., DELOST P., 1977. Changes in the concentrations of aldosterone in the plasma and adrenal glands of the foetus, the newborn and the pregnant guinea-pig during the perinatal period. Acta endocrinol., 84, 133-141.

GUÉGUEN L., 1978. Minéraux, 129-142. In Alimentation des Ruminants. INRA Publications, Versailles.

KINSON G. A., SINGER B., 1968. Sentivity to angiotensin and adrenocorticotrophic hormone in the sodium-deficient rat. Endocrinology, 83, 1108-1116.

KOJIMA I., KOJIMA K., RASMUSSEN A., 1985. Role of calcium and CAMP in the action of adrenocorticotropin on aldosterone secretion. J. biol. Chem., 260, 4248-4256.

McCAA R. E., LAUGFord H. G., MONTALVO J. M., ANDY O. J., READ V. H., McCAA C. S., 1981. Regulation of aldosterone biosynthesis during sodium deficiency. Evidence for an essential role of the pituitary gland. Hypertension, 3, (suppl. 1), I-74-I-80.

McDoUgALL J. G., SCOGgINS B. A., BUTKUS A., COGHLAN J. P., DENTON D. A., FEI D. T., HARDY K. J., WRIGHT R. D., 1981. Dopaminergic modulation of aldosterone secretion. $J$. Endocr., 91, 271-280.

McKENNA T. J., ISLAND D. P., NICHOLSON W. E., LIDDLE G. W., 1979. Dopamine inhibits angiotensin-stimulated aldosterone biosynthesis in bovine adrenal cells. J. clin. Invest., 64, 287-291.

NICHOLLS M. G., ESPINER E. A., DONALD R. A., 1975. Plasma aldosterone response to low-dose ACTH stimulation. J. clin. Endocrinol. Metab., 41, 186-188.

PERINGER E., JENNER P., DONALDSON I. M., MARSDEN C. D., 1976. Metoclopramide and dopamine receptor blockade. Neuropharmacology, 15, 463-469.

RACZ K., BUU N. T., KUCHEL D., DE LEAN A., 1984. Dopamine 3 sulfate inhibits aldosterone secretion in cultured bovine adrenal cells. Am. J. Physiol., 247, E431-E435.

RIAD F., LEFAIVRE J., TOURNAIRE C., BARLET J. P., 1986. Aldosterone regulates salivary sodium in cattle. J. Endocr., 108, 405-411.

RIAD F., GIRY J., BARLET J. P., 1987. Role du système rénine-angiotensine pendant la déplétion sodée chez les Bovins. J. Physiol. (Paris), 82 (sous presse).

SAFWATE A., 1985. Urinary sodium excretion and the renin-aldosterone system in newborn calves. J. Physiol. (London), 362, 261-271.

SAFWATE A., TOURNAIRE C., DALLE M., BARLET J. P., 1985. Lack of effect of metoclopramide on plasma aldosterone concentration in young calves. J. Physiol. (Paris), 80, 336-339.

SOWERS J. R., SHARP B., LEVIN E. R., GOLUB M. S., EGGENA P., 1981. Metoclopramide, a dopamine antagonist, stimulates aldosterone secretion in Rhesus monkeys, but not in dogs or rabbits. Life Sci., 29, 2171-217.

SOWERS J. R., BECK F. W. J., STERN N., ASP N., 1983. Effects of metoclopramide on plasma corticosteroid level in sheep. Endocrinology, 113, 903-906. 